\title{
INFORMATION WARFARE
}

\author{
УДК 004.056.53
}

ВОЛОДИМИР МОХОР, ОКСАНА ЦУРКАН

\section{НЕГАТИВНИЙ ІНФОРМАЦЙНО-ПСИХОЛОГІЧНИЙ ВПЛИВ НА ІНДИВІДУАЛЬНУ СВІДОМІСТЬ ЗА СОЦІОІНЖЕНЕРНИМ ПІДХОДОМ}

Розглянуто інформаційно-психологічний вплив на індивідуальну свідомість. Встановлено, що такий вплив носить не тільки конструктивний, позитивний характер, але й деструктивний, негативний стосовно особистості. До цього призводять як внутрішні фактори, так і фактори зовнішнього середовища. Індивідуально-психологічні властивості особистості впливають на їі дії, вчинки, поведінку в процесі життєдіяльності. Тому саме від них залежить не тільки успішне здійснення негативного інформаційно-психологічного впливу, але i протистояння йому. Проаналізовано напрями досліджень шляхів подолання цієї проблеми. Серед них виокремлено здійснення негативного інформаційно-психологічного впливу за соціоінженерним підходом. Цей вибір обумовлений тим, що результат психологічної взаємодії міжособистісного спілкування виявляється в зміні емоційного стану, поведінки або внутрішніх установок хоча б однієї з взаємодіючих сторін для досягнення поставленої цілі, а саме несанкціонованого доступу до інформації. Методи соціальної інженерії спрямовані на таку зміну психіки, при якій змінюється об’єктивна реальність, умови діяльності. Досягається така зміна завдяки негативному інформаційно-психологічному впливові на індивідуальну свідомість через дію на психічний стан, відчуття, думки і вчинки людини за допомогою винятково психологічних засобів. Особливістю такого впливу є те, що людина може не помічати його i не сприймати його як загрозу. Це обумовлено тим, що він не завжди усвідомлюється, призводить до створення ілюзій щодо дійсності, програмування мотивів до співпраці, прихованого управління. 3 огляду на це запропоновано шляхи забезпечення безпеки індивідуальної свідомості від негативного інформаційно-психологічного впливу за соціоінженерним підходом.

Ключові слова: індивідуальна свідомість, негативний інформаційно-психологічний вплив, соціоінженерний підхід, соціальна інженерія, інформаційно-психологічна безпека.

Вступ. В умовах наявності великих обсягів інформації в соціальному просторі людина пристосувалася до сприйняття інформаційного потоку, але не завжди іiі свідомість/підсвідомість контролює вплив інформації на іiі особистість, що призводить до зміни в регуляції діяльності, поведінки чи окремих дій. Такі дії називаються впливом. Вплив на особистість, піi психо-фізіологічні особливості і процеси через засоби та методи інформаційного змісту називається інформаційно-психологічним впливом.

Оскільки людина існує в соціумі і інформацію сприймає через технічні засоби та у процесі безпосередньої комунікації, інформаційно-психологічний вплив за рівнями може бути індивідуально-психологічним та соціально-політичним. Інформаційно-психологічний вплив може носити не тільки конструктивний, позитивний характер, але й бути деструктивним, негативним по відношенню до особистості. Якщо за його основу взято способи, засоби, методи впливу на свідомість особистості для здійснення виключно корисливих цілей, то такий метод впливу буде негативним.

Причинами уразливостей особистості до негативного інформаційно-психологічного впливу можуть бути як внутрішні фактори (індивідуальні психологічні або фізіологічні властивості, порушення емоційного стану, недостатність знань і досвіду), так і фактори зовнішнього середовища. I ті й інші психологічні властивості особистості (уразливості,

(C) B. Мохор, О. Цуркан, 2017 
слабкості) впливають на іiі дії, вчинки, поведінку в процесі життєдіяльності. Тому саме від індивідуальних психологічних особливостей залежить не тільки успішне здійснення негативного інформаційно-психологічного впливу, але і протистояння йому. Для того, щоб розробити технології та механізми забезпечення інформаційно-психологічної безпеки особистості важливо знати не стільки як протистояти інформаційно-психологічному впливу, стільки як реалізуються механізми негативного інформаційно-психологічного впливу і на стільки він $є$ руйнівним.

Аналіз останніх досліджень і публікацій. Запобігання використанню механізмів негативного інформаційно-психологічного впливу $\epsilon$ міждисциплінарною проблемою $\mathrm{i}$ вивчається спільними зусиллями психологів, педагогів, фізиків, медиків, гігієністів та фахівців з безпеки. Це обумовлено тим, що забезпечення інформаційно-психологічної безпеки гостро стоїть на державному рівні. Так, вітчизняними та зарубіжними науковцями досліджуються такі аспекти вирішення означеної проблеми, наприклад: інформаційні війни [1], [5], [6]; принципи маніпулятивного впливу [12], [13], [14], [15]; інформаційнопсихологічна безпека, інформаційно-психологічні впливи [1], [2], [3], [7], [16]; вплив деструктивних груп [8], [15]; забезпечення інформаційної безпеки у соціальних інтернетсервісах [14]. При цьому доцільно зазначити, що у своїх працях науковці здебільшого визначають інформаційно-психологічну безпеку як відсутність небезпеки інформаційнопсихологічних впливів, зокрема, й за соціоінженерним підходом.

Метою роботи $\mathbf{\epsilon}$ аналіз негативного інформаційно-психологічного впливу на індивідуальну свідомість за соціоінженерним підходом.

Дослідження даного напрямку має як практичне, так і теоретичне значення. Практичне значення досліджень полягає в тому, що навіть з розвитком сучасних технологій (існуванням сучасних психологічних практик, способів і методів захисту від негативного інформаційнопсихологічного впливу) та достатнім доступом до інформації, людина не розуміє і не знає якими психологічними способами та методами користуватися, щоб захистити себе, запобігти негативному інформаційно-психологічного впливу [16]. Проблема має теоретичне значення, оскільки людина постійно перебуває у міжособистісній взаємодії, і негативний інформаційнопсихологічний вплив може виявлятися і розглядатися як характеристика, як складова особистості [9].

Виклад основного матеріалу дослідження. За соціоінженерним підходом негативний інформаційно-психологічний вплив розуміється як результат психологічної взаємодії міжособистісного спілкування через інформаційно-психологічний вплив, що виявляється в зміні емоційного стану, поведінки або внутрішніх установок хоча б однієї з взаємодіючих сторін для досягнення поставленої цілі, а саме несанкціонованого доступу до інформації [16].

Методи соціальної інженерії спрямовані на таку зміну психіки, при якій змінюється об'єктивна реальність, умови діяльності. Досягається така зміна перевагою у впливі на свідомість (підсвідомість), хоча вплив може бути свідомим та несвідомим, позитивно або негативно позначатись на поведінці людини.

Терміни “психологічний вплив" і “психологічна взаємодія" мають однакові мотиви і переслідують одну і ту ж мету, але досягаються різними механізми, хоча із використанням одних і тих же методів і засобів. Інформаційно-психологічного вплив здійснюється однією особистістю на психіку іншої особистості, тобто одна особистість здатна своєю дією вносити зміни у поведінку й діяльність іншої. Тоді як психологічна взаємодія об'єднує двохсторонні дії психологічного впливу, під час яких, дії однієї особистості зумовлюють дії іншої, і навпаки, коли особистість, що впливає змінює власну поведінку внаслідок дій особистості на яку вона впливає [4]. Таким чином, кожен учасник водночас і об'єкт, і суб'єкт інформаційнопсихологічного впливу [15]. Структурно негативний інформаційно-психологічного вплив включає в себе наступні компоненти:

- суб'єкт - той, хто здійснює негативний вплив;

- об’єкт - той, хто піддається негативному впливу; 
- способи впливу - технічні прийоми, що використовуються для здійснення негативного впливу;

- засоби впливу - технічні чи інформаційно-психологічні засоби, що використовуються для здійснення негативного впливу;

- механізми впливу - інформаційно-психологічні механізми (інакше, непрямі методи впливу).

Засоби, які використовуються суб'єктом впливу, залежать від конкретного виду впливу. Вплив може бути безпосереднім (у процесі міжособистісного спілкування) i опосередкованим, наприклад, різними технічними засобами [1], [16].

Негативний інформаційно-психологічний вплив за соціоінженерним підходом здійснюється через дію на психічний стан, відчуття, думки і вчинки людини за допомогою винятково психологічних засобів: вербальних, невербальних та пара лінгвістичних [12].

Застосування вербальних засобів сприяє усвідомленому сприйняттю змісту інформації. Застосування невербальних засобів веде до підсвідомого сприйняття інформації, через вплив на індивідуально-психологічні особливості особистості - уразливості (слабкості). На практиці застосовують паралінгвістичний засіб впливу та його різновиди інформаційно-енергетичний, психофізіологічний впливи:

- психогенний;

- нейролінгвістичний;

- психоаналітичний (психокорекційний);

- психотронний (парапсихологічний, екстрасенсорний);

- психотропний.

Останні впливи недостатньо вивчені, але широко застосовуються, тому особливо небезпечні і негативно впливають як на психічну так і на фізіологічну сторону особистості [7].

Можливість застосування соціальних або фізичних засобів, також повинні вважатися психологічними засобами, принаймні, доти, поки ці загрози не приводять в дію.

Інформаційно-психологічний вплив негативно відображається в різних сферах особистості іншої людини:

1) вплив на когнітивну сферу здійснюється з метою змінити знання, уявлення іншої людини;

2) вплив на емоційну сферу здійснюється з метою змінити емоційний стан людини;

3) вплив на мотиваційну сферу спрямовано на зміну мотивів i, як наслідок, поведінки людини.

Часто використовується комплексний вплив - на всі сфери особистості, оскільки в цьому випадку вплив буде найбільш ефективним [10], [11].

До механізмів негативного інформаційно-психологічного впливу відносяться різні механізми і ефекти соціальної перцепції, механізми і феномени сприйняття, пам'яті, уваги тощо. Це такі механізми як: ідентифікація, емоційне зараження, навіювання, емпатія, наслідування, переконання. Вони можуть не усвідомлюватися самим суб'єктом впливу. У багатьох випадках непрямі методи впливу можуть виявитися набагато ефективніше i дозволять досягти того ж результату меншими зусиллями.

Застосування засобів і механізмів негативного інформаційного впливу на свідомість людини дозволяють програмувати дії та поведінку людини для маніпулювання нею.

Для ефективного захисту від маніпуляцій необхідно вміти їх розпізнавати [3]. Виокремлюють і класифікують такі механізми маніпуляцій:

1) визначення вектора впливу згідно із завданням;

2) підбір засобів для здійснення впливу;

3) пошук мотиву, через який можна проникнути у психічну сферу - „влізти в душу”;

4) поступове нарощування тиску у різних напрямах (якщо необхідно): підвищення щільності (ряд близьких за змістом чи за формою впливів); тотальність впливу - його різноплановість, різноманітність каналів і мішеней; постійність - наполегливість, що доходить до настирливості; інтенсивність - підвищення сили впливу. 
Для досягнення мети методами соціальної інженерії, які реалізуються в процесі психологічної взаємодії міжособистісного спілкування використовують і таке поняття, як “модель”. Виділяють п'ять моделей (типів) спілкування при реалізації негативного інформаційно-психологічного впливу: запобігливий, звинувачувальний, розважливий, віддалений і врівноважений [17].

Особливістю негативного інформаційно-психологічного впливу на індивідуальну свідомість $\epsilon$ те, що людина може не помічати його і не усвідомлювати як загрозу.

Негативний інформаційно-психологічний вплив на свідомість особистості різними методами соціальної інженерії дозволяє:

- здійснювати вплив таким чином, що він лишається непоміченим;

- керувати волею, почуттями і настроєм об'єкта впливу;

- доводити об'єкт впливу до стану інертності шляхом прихованого примусу, програмування думок, намірів, установок, поведінки;

- приховувати дійсну інформацію від об'єктів впливу;

- спонукати поведінку об'єкта впливу обманом або грою на його передбачуваних уразливостей (слабостях).

Негативний інформаційно-психологічний вплив передбачає використання низки прийомів соціальної інженерії, що підвищують його ефективність:

- подавання потрібної у даний момент, найчастіше грубо сфабрикованої інформації;

- навмисне утаювання дійсної інформації;

- інформаційне перевантаження, що ускладнює можливість об’єкту впливу розібратися у дійсному стані справ.

Висновки. Негативний інформаційно-психологічний вплив на індивідуальну свідомість це:

- психологічний вплив на особистість, який не завжди нею усвідомлюється і змушує iii діяти відповідно до цілей того, хто впливає;

- штучний процес створення суб'єктом ілюзій щодо дійсності (або щодо себе), які сприймаються іншими суб' єктами (або й самим творцем ілюзій);

- особливий вплив на підсвідомість людини (переважно на іï емоції, почуття i переживання) з метою програмування мотиву партнера до співпраці;

- приховане управління особистістю всупереч ㄲï волі, яке приносить ініціаторові односторонні переваги;

- вид психологічного впливу, майстерне виконання якого викликає приховане пробудження у іншої особистості намірів, які не співпадають з їі актуальними бажаннями.

Кінцевою його метою завжди $є$ досягнення певної реакції, поведінки (дії або бездіяльності) особистості, яка відповідає цілям негативного інформаційно-психологічного впливу за соціоінженерним підходом. При цьому за допомогою негативного інформаційнопсихологічного впливу, можна змінювати життєві установки людей у потрібному напрямку, зокрема, отриманню несанкціонованого доступу до інформації. Ефективність такого впливу великою мірою залежить від уміння і своєчасності застосування всіх його засобів і форм.

Для забезпечення захисту психіки і свідомості/підсвідомості від негативного інформаційно-психологічного впливу за соціоінженерним підходом потрібно формувати $\mathrm{i}$ розвивати механізми фізіологічної та психічної саморегуляції особистості, захисту від проникнення в свідомість/підсвідомість, систему індивідуального, вибіркового, свідомого ставлення, сприйняття інформації, а саме - критичне мислення особистості. А для цього потрібно розробляти і впроваджувати навчальні, профілактичні (випереджувальні) заходи і заходи протидії та нейтралізації негативного інформаційно-психологічного впливу [1] - [3].

\section{СПИСОК ВИКОРИСТАНОЇ ЛІТЕРАТУРИ}

[1] В.Л. Бурячок, С.В. Толюпа, В.В. Семко, Л.В. Бурячок, П.М. Складанний, та Н.В. ЛуковаЧуйко, Інформаційний та кіберпростори: проблеми безпеки, методи та засоби боротьби. Київ, Україна: ДУТ - КНУ, 2016. 
P-ISSN 2411-1031. Information Technology and Security. July-December 2017. Vol. 5. Iss. 2 (9)

[2] Міністерство інформаційної політики України. (2015, Черв. 5). Проект Концепиї інформаційної безпеки України. [Електронний ресурс]. Доступно: http://mip.gov.ua/done_img/d/30-project_08_06_15.pdf. Дата звернення: Серп. 07, 2017.

[3] В.Л. Бурячок, Р.В. Грищук, та В.О. Хорошко, Політика інформаційної безпеки, Київ, Україна: ПВП “Задруга”, 2015.

[4] Т.Б. Гриценко, Етика ділового спілкування. Київ, Україна: Центр учбової літератури, 2007.

[5] Р.В. Грищук, та Ю.Г. Даник, Основи кібернетичної безпеки. Житомир, Україна: ЖНАЕУ, 2016.

[6] В.А. Ліпкан, “Сутність гібридної війни проти України”, Імперативи розвитку цุивілізації, № 2, c. 13-16, 2015.

[7] Я.М. Жарков, В.М. Петрик, М.М. Присяжнюк, Є.Д. Скулиш, та Л.Ф. Компанцева, Інформаційно-психологічне протиборство (еволючія та сучасність). Київ, Україна: Віпол, 2013.

[8] В.М. Шлапаченко, “Дезінформація як спосіб інформаційно-психологічного впливу”, Інформачійна безпека людини, суспільства, держави, № 2 (12), с. 79-86, 2013.

[9] Х.Ю. Хворост, Психологічні засади інформачійної позичії особистості. Луцьк, Україна: Вежа-Друк, 2016.

[10] П.С. Атаманчук, В.В. Мендерецький, О.П. Панчук, та О.Г. Чорна, Безпека життєдіяльності. Київ, Україна: Центр учбової літератури, 2011.

[11] Ж. Вірна, та Х.Хворост, Психологія професійної безпеки: технології конструктивного самозбереження особистості. Луцьк, Україна: Вежа-Друк, 2015.

[12] Г.В Грачев, и И.К. Мельник, Манипулирование личностью: организащия, способы и технологии информационно-психологического воздействия. Москва, Российская Федерация: Алгоритм, 2002.

[13] Е.Л. Доценко, Психология манипулящии: феномены, механизмы и защита. Москва, Российская Федерация: Издательство МГУ, 1997.

[14] Ю.Я. Поліщук, С.О. Гнатюк, та Н.А. Сєйлова, “Мас медіа як канал маніпулятивного впливу на суспільство", Безпека інформаиії, т. 21, № 3, с. 301-308, 2015. doi: 10.18372/2225-5036.21.9709.

[15] Б.В. Остроухов, Б.М. Петрик, та М.М. Присяжнюк, Інформащійна безпека (соиіальноправові аспекти). Київ, Україна: КНТ, 2010.

[16] О.В. Цуркан, В.В. Мохор, та Р.П. Герасимов, “Маніпулятивна форма соціоінженерного впливу на особистість в кіберпросторі”, на Всеукр. наук.-практ. конф. Актуальні проблеми управління інформащійною безпекою держави, Київ, 2015, с. 303-304.

[17] Т.К. Чмут, Г.Л. Чайка, М.П. Лукашевич, та І.Б. Осечинська, Етика ділового спілкування. Київ, Україна: МАУП, 2003.

Стаття надійшла до редакції 18 серпня 2017 року.

\section{REFERENCE}

[1] V.L. Buriachok, S.V. Toliupa, V.V. Semko, L.V. Buriachok, P.M. Skladannyi, and N.V. Lukova-Chuiko, Information and cyberspace: security problems, methods and means of struggle. Kyiv, Ukraine: DUT - KNU, 2016.

[2] Ministry of Information Policy of Ukraine. (2015, Jun. 5). Draft Concept of Information Security of Ukraine. [Online]. Available: http://mip.gov.ua/done_img/d/30-project_08_06_ 15.pdf. Accessed on: Aug. 07, 2017.

[3] V.L. Buriachok, R.V. Hryshchuk, and V.O. Khoroshko, Information security policy, Kyiv, Ukraine: PVP “Zadruha”, 2015.

[4] T.B. Hrytsenko, Ethics of business communication. Kyiv, Ukraine: Center of educational literature, 2007. 
[5] R.V. Hryshchuk, and Y.H. Danyk, Fundamentals of cyber security. Zhytomyr, Ukraine: ZHNAEU, 2016.

[6] V.A. Lipkan, "The essence of hybrid war against Ukraine", Imperatives of the development of civilization, no. 2, pp. 13-16, 2015.

[7] Y.M. Zharkov, V.M. Petryk, M.M. Prysiazhniuk, Y.D. Skulysh, and L.F. Kompantseva, Information-psychological confrontation (evolution and modernity). Kyiv, Ukraine: Vipol, 2013.

[8] V.M. Shlapachenko, "Misinformation as a means of information-psychological influence", Information security of the Person, Society and State, no. 2 (12), pp. 79-86, 2013.

[9] K.Y. Khvorost, Psychological principles of the informational position of the individual. Lutsk, Ukraine: Vezha-Druk, 2016.

[10] P.S. Atamanchuk, V.V. Menderetskyi, O.P. Panchuk, and O.H. Chorna, Life Safety. Kyiv, Ukraine: Center of educational literature, 2011.

[11] Z. Virna, and K. Khvorost, Psychology of professional safety, technology constructive self identity. Lutsk, Ukraine: Vezha-Druk, 2015.

[12] G.V. Grachev, and I.K. Melnik, Manipulation by personality: the organization, methods and technologies of information-psychological impact. Moskow, Russia: Algorithm, 2002.

[13] E.L. Dotsenko, Psychology of manipulation: phenomena, mechanisms and protection. Moskow, Russia: MSU Publishing House, 1997.

[14] Yu. Polishchuk, S. Gnatyuk, N. Seilova, "Mass media as a channel of manipulative influence on society", Bezpeka informaciì, vol. 21, no. 3, pp. 301-308, 2015.

doi: 10.18372/2225-5036.21.9709.

[15] B.V. Ostroukhov, B.M. Petryk, and M.M. Prysiazhniuk, Information security (socio-legal aspects). Kyiv, Ukraine: KNT, 2010.

[16] O.V. Tsurkan, V.V. Mokhor, and R.P. Herasymov, "Manipulative form of socioengineering impact on personality in cyberspace ", in Proc. Ukrainian scientific and practical conference. Actual problems of information security management of the state, Kyiv, 2015, pp. 303-304.

[17] T.K. Chmut, H.L. Chaika, M.P. Lukashevych, and I.B. Osechynska, Ethics of business communication. Kyiv, Ukraine: MAUP, 2003.

\section{ВЛАДИМИР МОХОР, ОКСАНА ЦУРКАН}

\section{НЕГАТИВНОЕ ИНФОРМАЦИОННО-ПСИХОЛОГИЧЕСКОЕ ВЛИЯНИЕ НА ИНДИВИДУ АЛЬНОЕ СОЗНАНИЕ ПО СОЦИОИНЖЕРНОМУ ПОДХОДУ}

Рассмотрено информационно-психологическое влияние на индивидуальное сознание. Такое влияние носит не только конструктивный, положительный характер, но и деструктивный, негативный по отношению к личности. К этому приводят как внутренние факторы, так и факторы внешней среды. Индивидуально-психологические свойства личности влияют на ее действия, поступки в процессе жизнедеятельности. Поэтому именно от них зависит не только осуществление негативного информационно-психологического влияния, но и противостояние ему. Проанализированы направления исследований путей преодоления этой проблемы. Среди них выделено осуществление информационно-психологического влияния по социоинженерному подходу. Этот выбор обусловлен тем, что результат психологического взаимоодействия межличностного общения проявляется в изменение емоционального состояния, поведения или внутренних установок хотя бы одной из взаимодействующих сторон для достижения поставленой цели, а именно несанкционированого доступа к информации. Методы социальной инженерии направлены на такое изменение сознания, при котором измениятеся объективная реальность, условия деятельности. Такое изменение достигается вследствии негативного информационно-психологическому влиянию на индивидуальное сознание путем воздействия на психологическое состояние, чувства, мысли и поступки человека с помощью психологических средств. Особеностью такого влияния является то, что человек может не замечать и не воспринимать его как угрозу. Это обусловлено тем, что он не всегда осознается, приводит к созданию илюзий относительно действительности, 
программирования мотивов к сотруднечеству, скрытому управлению. Исходя из этого предложено пути обеспечения безопасности индивидуального сознания от негативного информационно-психологического влияния по социоинженерному подходу.

Ключевые слова: индивидуальное сознание, негативное информационнопсихологическое влияние, социоинженерный подход, социальная инженерия, информационно-психологическая безопасность.

VOLODYMYR MOKHOR, OKSANA TSURKAN

\section{NEGATIVE INFORMATION-PSYCHOLOGICAL IMPACT ON INDIVIDUAL CONSCIOUSNESS BASED ON SOCIO-ENGINEERING APPROACH}

The information-psychological impact on individual consciousness is considered. It is established that such influence has not only constructive, positive character, but also destructive, negative in relation to the personality. Internal and environmental factors lead to this. Individualpsychological properties of the individual affect her actions, acts, behavior in the process of life. Therefore, it not the only successful implementation of negative information and psychological impact depends on them but also opposition to it. The research directions of ways overcoming this problem were analyzed. Among them allocated, the implementation of negative informationpsychological impact based on the socio-engineering approach. This choice is caused to the fact that the result of the psychological interaction of interpersonal communication is shown in the change emotional state, behavior or internal attitudes at least by the one interacting side to achieve the stated goal, namely unauthorized access to information. Social engineering methods are aimed for such a change in the psyche at which the objective reality changes, the conditions of activity. Such a change achieved due to the negative information-psychological impact on the individual consciousness through the impact on the person's mental state, feelings, thoughts and actions with exclusively psychological means. The features of such influences are that the person can ignore it and not realize it as the threat. This caused by the fact that it didn't always realize, leads to the creation of illusions concerning reality, programming of motives to cooperation, the hidden management. Given this, the ways of ensuring the individual security consciousness from the negative information-psychological impact based on socio-engineering approach are proposed.

Keywords: individual consciousness, negative informational and psychological impact, socioengineering approach, social engineering, information and psychological security.

Володимир Володимирович Мохор, доктор технічних наук, професор, директор, Інститут проблем моделювання в енергетиці ім. Г.Є. Пухова Національної академії наук України, Київ, Україна.

E-mail: v.mokhor@gmail.com.

Оксана Володимирівна Цуркан, провідний інженер відділу науково-технічої інформації, Інститут проблем моделювання в енергетиці ім. Г.С. Пухова Національної академії наук України, Київ, Україна.

E-mail: o.tsurkan24@gmail.com.

Владимир Владимирович Мохор, доктор технических наук, профессор, директор, Институт проблем моделирования в энергетике им. Г.Е. Пухова Национальной академии наук Украины, Киев, Украина.

Оксана Владимировна Цуркан, ведущий инженер отддела научно-технической информации, Институт проблем моделирования в энергетике им. Г.Е. Пухова Национальной академии наук Украины, Киев, Украина.

Volodymyr Mokhor, doctor of technical sciences, professor, director, Pukhov institute for modeling in energy engineering of National academy of sciences of Ukraine, Kyiv, Ukraine.

Oksana Tsurkan, leading engineer at the scientific and technical information department, Pukhov institute for modeling in energy engineering of National academy of sciences of Ukraine, Kyiv, Ukraine. 